\title{
ANALYSIS OF THE POSSIBILITIES TO ACHIEVE THE LOW ENERGY RESIDENTIAL BUILDINGS STANDARDS
}

\author{
Małgorzata BASIŃSKA, Halina KOCZYK \\ Institute of Environmental Engineering, Faculty of Civil and Environmental Engineering, \\ Poznan University of Technology, Berdychowo 4 Street, 60-965, Poznan, Poland
}

Received 19 September 2015; accepted 11 June 2016

\begin{abstract}
The article applies the global costs calculation method to the energy assessment of selected solutions for the technical equipping of buildings, dependant on their purpose and function. Representative archetypes, the life span of which were assumed to be 30 -years, were used to estimate the performance of the minimum requirements according to the building regulations valid in 2013, current general standards, as well as low energy building and passive house standards. The subjects of the analysis were three residential buildings, for which the variability of the cladding and ventilation needs was assumed. In all analysed cases the application of four systems of energy supply to the building was also assumed. The optimal level of primary energy index value, dependant on the source of heat, was established by means of the global cost method. This level was then compared with the requirements presently valid in Poland. The analysis also allowed for the determination of the growth in investment costs, that must be considered in order to achieve the energy needed for heating and ventilation at the level of $40 \mathrm{kWh} / \mathrm{m}^{2} / \mathrm{a}$ or $15 \mathrm{kWh} / \mathrm{m}^{2} / \mathrm{a}$. The analysis presents a comparison of the subsidized loans for energy-efficient houses offered by the Polish Government.
\end{abstract}

Keywords: global cost methodology, low energy buildings, European Union Directive, support, government.

JEL Classification: R5.

\section{Introduction}

Issues related to energy saving have become an important subject in the contemporary world. As $42 \%$ of the energy produced in Europe is consumed by buildings, and $75 \%$ of this final energy is consumed exclusively by residential buildings, rules and design criteria for low energy buildings were established in the European Union. Moreover, appropriate building regulations were applied, referring to the building's heat protection.

Corresponding author Małgorzata Basińska

E-mail: malgorzata.basinska@put.poznan.pl 
According to the idea of sustainability, natural resources should be used in such a way so as to secure them for future generations. This means that buildings should be designed in a manner allowing for a constant decrease in the level of consumed energy during construction and long-term usage. Moreover, more pressure is being applied to ensure the usage of renewable energy for the purpose of low-energy buildings.

The beginning of the extensive activities related to this subject was a European Directive, and later its amended version, the so called Energy Performance of Buildings Directive (EPBD) Recast (Directive 2010/31/EU).

The recast directive established several newer and strengthened requirements such as the obligation that all new buildings should reach nearly zero-energy levels by the end of 2020 .

Each member country may establish the individual levels for energy related requirements, but they must be consistent with the comparable methodology.

Such a comparative toll is part of a global costs method which can be applied in order to indicate the level of requirements described by means of a primary energy index for buildings and their components, as well as for buildings' external components, influencing in a significant way the building's energy characteristics. It must be highlighted that the method mentioned above is consistent with the Polish standard (PN EN 15459:2008) and can be used in calculations related to optimization of buildings and their technical systems.

It is worth mentioning that energy requirements for buildings were established in Poland using the global costs method.

Low energy building parameters are to be obtained in the years to come. The Polish government's target for reducing primary energy use per heated building area is $20 \%$ and $40 \%$ below 2014 levels by 2017 and 2021 respectively (Table 1).

Table 1. Energy requirements for buildings (Polish law: Dz. U., 926, 2013)

\begin{tabular}{cccc}
\hline Building & \multicolumn{3}{c}{$\mathrm{EP}_{\text {requiments }}, \mathrm{kWh} / \mathrm{m}^{2} / \mathrm{a}$} \\
\cline { 2 - 4 } & 2014 & 2017 & 2021 \\
\hline single-family & 120 & 95 & 70 \\
\hline multi-family & 105 & 85 & 65 \\
\hline
\end{tabular}

So far, in Poland the requirements regarding the heat protection of buildings have only taken into consideration a building's elements, so at present it is very important to also consider the cooperation of the building's technical installations. Achievement of the above targets is only possible if:

- the heat insulation of the building's cladding is improved,

- the air flow within the building's envelope is controlled,

- steps to increase the effectiveness of heat source usage are undertaken.

An evaluation of solutions applied to building components was presented in the works of Aviža, Turskis and Kaklauskas (Aviža, Turskis 2014; Aviža et al. 2015).

Aviža and Turskis presented a comparison of the standard requirements of " $\mathrm{C}$ " energy efficiency class buildings and "A++" class. The required thickness of a thermal insulation 
layer for the typical floor on-soil sample and price increase 4 times, annual savings - 1.3 times, and simple payback time - 3.1 times up to 4.62 years (Aviža, Turskis 2014). For that evaluation they applied the simple payback period method, not considering the change of time value of money. In the paper (Aviža et al. 2015) the authors evaluated usage of the appropriate thickness of walls to fulfil the requirements for heat insulation. Comparing the standard requirements for buildings of energy efficiency classes $\mathrm{C}$ and $\mathrm{B}$ with class $\mathrm{A}++$ net zero energy buildings, the required thickness of the thermal insulation layer for typical wall details and price increases 2.54 times while annual savings - increase 1.29 times (Aviža et al. 2015). The authors also paid attention to the fact that it is necessary to take into consideration the location, when evaluating the buildings. In the A category, the required thickness of the thermal insulation layer pertaining to the wall varies by $4 \mathrm{~cm}$ between the warmest and coldest region of Lithuania (Aviža et al. 2015).

During introduction of improved thermal requirements for buildings, within a certain time frame, attention must be given to the already existing buildings. Many of them require works related to the application of thermos-insulation.

A number of research papers are specifically dedicated to the subject of thermo-modernisation (Basinska et al. 2015a; Chidiac et al. 2011; Kurnitski et al. 2014; Ouyang et al. 2011; Pikas et al. 2015; Ruzgys et al. 2014; Tupenaite et al. 2010).

For example, using the multi- criteria optimization method Ruzgys and his team argued that the values of individual criteria have a greater influence on retrofit efficiency than the type of façade or insulation requirements both in the present and in the future (Ruzgys et al. 2014). The authors of this paper (Basinska et al. 2015a) showed that in the case of a building with relatively good thermal characteristics the introduction of building improvements and the additional costs related to mechanical ventilation is unprofitable.

Nevertheless, Pikas (Pikas et al. 2015) indicates that it is necessary to make a choice between continuing to live in buildings which are unhealthy and wasteful of energy and investing in integrated energy renovation in order to enjoy significant economic and environmental benefits.

The results of his research confirm that investing in energy efficiency is not only environmentally important but also provides economic benefits on both individual and government budget levels.

In recent years, in the publications of Kurnitski buildings energy evaluations have been presented by means of the global costs method (Kurnitski et al. 2011, 2013).

The analyses presented in Kurnitski's articles refer both to residential buildings and public utility buildings.

Aelenei (Aelenei et al. 2015) presents the application of the global costs method when choosing the optimum energy in selected countries of the European Union. Analyses were made of Italy, Portugal, Spain and Greece. However it is very difficult to apply the results from his paper to the situation in the Baltic countries mainly due to the different climate specifics and the economic conditions.

This method allows for analysis of the building not only as a structure but also takes into consideration its technical installations. Additionally, it indicates the costs of replacing the elements in the building, in the time. Residential buildings within a period of 30 years are analysed, assuming constant macroeconomic parameters. 
In the paper mentioned above (Basinska et al. 2015b), the authors noticed that the equalization of global cost shifts along with an increase in the investment costs and energy prices, and the cost-effectiveness of energy saving solutions increases with a decrease in inflation.

The global cost method allows one to establish requirements dependant on the type of building and the means of energy supply. The global cost method can also be a very good tool for evaluating the achievements of energy policies which tend to increase the number of low energy buildings being constructed.

In this paper, the possibilities of performing the European Directive under the energy policy for buildings in Poland are presented, taking into consideration data regarding the Polish economy. It also presents an evaluation of the economic tools supporting energysaving solutions in the Polish economic environment.

The goal of the paper is to estimate the increase in costs related to the construction, exploitation and recreation of low-energy buildings in relation to the costs incurred when constructing the buildings in accordance with the presently valid standards and regulations.

The paper provides a description of the assumptions of the global costs method used in the European Union to indicate the requirements of a building's energy characteristics. The paper first highlights the choice of optimal indicator of the primary energy for three of the analysed buildings and four sources of heat. The analysis was made using constant economic parameters. Finally, the method was applied to evaluate the loans offered by the Polish state for low energy buildings.

In the paper, the increased expenditure related to achievement of the low energy building standard NF40 (used energy at the level of $40 \mathrm{kWh} / \mathrm{m}^{2} / \mathrm{a}$ ) and NF15 (used energy at the level of $15 \mathrm{kWh} / \mathrm{m}^{2} / \mathrm{a}$ ) was evaluated. Last but not least, the effectiveness of this economic tool was also a subject of the analysis.

\section{Methods}

The global costs method was applied in order to determine the optimal energy rate for primary energy. The framework conditions for the calculations have to be defined in terms of climate data, performance of energy systems and macroeconomic conditions. This method allows for the selection of cases where the positive effects of energy savings are the greatest. Additionally, it allows for complex presentation of matters regarding the building's occupancy, the applied materials and components as well as energy sources.

\subsection{Methodology for the calculation of energy performance}

Polish standards were applied to calculations of the energy performance of building (Dz.U. nr 201, poz.1240. 2008.). For determination of the building's energy needs for space heating the static method was used. The method applied was based on monthly balances taking into account by the relation (1):

- transmission heat losses $-H_{t r}$,

- heat losses through infiltration and ventilation heat losses $-H_{v e}$, 
- solar heat gains $-Q_{s o l}$,

- internal heat gains - $Q_{\text {int }}$.

The analysis takes into consideration the coefficient of efficiency of heat gains $-\eta_{H, g n}$. The authors (Basinska et al. 2015b) have previously presented a detailed flow diagram of the calculations made for usable energy.

$$
Q_{H, n d}=\sum_{m=1}^{m_{H}}\left[\begin{array}{l}
\left(\sum_{k=1}^{k_{x}} H_{t r, k}+H_{v e}\right) \cdot\left(\theta_{\mathrm{int}, H}-\theta_{e, m}\right) \cdot t_{m}+ \\
-\eta_{H, g n, m} \cdot\left(Q_{s o l, g n, m}+Q_{\mathrm{int}, m}\right)
\end{array}\right],
$$

where: $Q_{H, n d}$ - the building energy needed for space heating, $\mathrm{kWh} / \mathrm{a} ; H_{t r}-$ the heat transfer coefficient by transmission, W/K; $H_{v e}$ - the heat transfer coefficient by ventilation, W/K; $k$ - the index of heat transfer coefficient by transmission; $k_{x}$ - the number of heat transfer coefficient by transmissions; $\theta_{i n t, H}$ - the temperature for heating of space, ${ }^{\circ} \mathrm{C} ; \theta_{e, m}-$ the monthly temperature of the external environment, ${ }^{\circ} \mathrm{C} ; t_{m}$ - the number of hours in the month; $\eta_{H, g n, m}$ - the monthly gain utilization factor; $Q_{s o l, m}$ - the monthly solar heat gains for the heating mode, $\mathrm{kWh} /$ month; $Q_{i n t, m}$ - the monthly internal heat gains for the heating mode, $\mathrm{kWh} / \mathrm{month} ; \mathrm{m}$ - the index of months in the heating season; $m_{H}$ - the number of months in the heating season.

The usable energy for the purpose of hot water preparation is established based on the dependency presented below:

$$
Q_{W, n d}=\frac{\dot{V}_{W} \cdot l m \cdot c_{W} \cdot \rho_{W} \cdot\left(\theta_{W}-\theta_{10}\right) \cdot t}{3600},
$$

where: $Q_{W, n d}$ - the energy needed for hot water preparation, $\mathrm{kWh} / \mathrm{a} ; \dot{V}_{W}-$ the unit of diurnal demand for hot usable water, $\mathrm{dm}^{3} /$ person $/ \mathrm{d}$; $l m$ - the number of people; $c_{W}$ - the specific heat capacity of water $4.19 \mathrm{~kJ} / \mathrm{kg} / \mathrm{K} ; \rho_{w}$ - the density of water, $\mathrm{kg} / \mathrm{m}^{3} ; \theta_{\mathrm{w}}-$ for calculation purposes, the temperature of the hot water in the intake valve is equal to $55^{\circ} \mathrm{C}$; $\theta_{10}$ - for calculation purposes, the temperature of the water before heating is equal to 10 ${ }^{\circ} \mathrm{C} ; t$ - the number of days the hot water preparation system works during the year.

For determination of final energy demands, overall system efficiency was used. The final energy calculation takes into account losses associated with the technical installations of the building on the side of emission, distribution, storage and generation and includes all energy according to the equation (3):

$$
Q_{K, i}=\frac{Q_{i, n d}}{\eta_{i, e} \cdot \eta_{i, d} \cdot \eta_{i, s} \cdot \eta_{i, g}},
$$

where: $Q_{K, i}$ - the final energy for the chosen purpose, $\mathrm{kWh} / \mathrm{a} ; Q_{i, n d}-$ the building's energy needs, $\mathrm{kWh} / \mathrm{a} ; \eta_{\mathrm{i}, \mathrm{e}}$ - regulation efficiency; $\eta_{i, d}$ - distribution efficiency; $\eta_{i, s}$ - storage efficiency; $\eta_{i, g}$ - generation efficiency; $i$ - the index of the system ( $\mathrm{i}=\mathrm{H}$ - heating, $\mathrm{i}=\mathrm{W}-$ hot water preparation).

Under the current provisions, the primary energy ratio as a function of the parameters given in equation (4), is attributed to the heated net floor area of the controlled temperature $\mathrm{A}_{\mathrm{f}}$ (EP ratio): 


$$
E P=\frac{Q_{K, H} \cdot w_{H}+Q_{K, W} \cdot w_{W}+E_{e l, a u x} \cdot w_{e l}}{A_{f}},
$$

where: $E P$ - the primary energy ratio, $\mathrm{kWh} / \mathrm{m}^{2} / \mathrm{a} ; Q_{K, H}$ - the final energy for heating and ventilation, $\mathrm{kWh} / \mathrm{a} ; Q_{K, W}$ - the final energy for hot water preparation, $\mathrm{kWh} / \mathrm{a} ; E_{\text {el, aux }}$ - the annual demand for final electrical energy to drive the auxiliary devices of the given system, $\mathrm{kWh} / \mathrm{a} ; w$ - the expenditure coefficient of non-renewable primary energy to generate and supply the final energy carrier (or energy) to the evaluated building, which is determined by the energy or energy carrier supplier $\left(w_{e l}-\right.$ for electricity, $w_{H}-$ for heating, $W_{w}-$ for hot water preparation; $A_{f}-$ heated net floor area; $\mathrm{m}^{2}$ ).

To carry out the analyzes, representative data available on the Polish Ministry of Infrastructure and Development website were used (MIiD 2015), comprising some typical meteorological years designated on the basis of information provided by the Institute of Meteorology and Water Management. Values for the design's indoor air temperature were adopted in accordance with accepted standards (PN EN 15251:2012).

\subsection{Energy costs}

Electrical and thermal energy as well as natural gas are supplied to buildings in a continuous way from the transmission network, and the price of their consumption is calculated according to a two-part tariff. The fixed part depends on so called ordered power (in the case of gas, on the declared volume of fuel consumption during the year), while the variable part depends on the amount of supplied energy or gas.

The fee for the provision of comprehensive services of fuel delivery $\mathrm{C}_{\mathrm{Q}}$ is calculated from the formula:

$$
C_{Q}=C \cdot Q_{K, i}+S_{z s} \cdot Q_{K, i}+S_{s s} \cdot m+S_{a} \cdot m
$$

where: $C_{Q}$ - the cost of energy, PLN; $Q_{K^{\prime} i}$ - the final energy for the chosen fuel, $\mathrm{kWh} / \mathrm{a} ; C$ the price of the energy carrier, PLN $/ \mathrm{m}^{3}, \mathrm{PLN} / \mathrm{kWh} ; S_{z s}$ - the network rate of the variable fee, PLN/m ${ }^{3}$, PLN/kWh; $S_{s s}$ - the network rate of the fixed charge, PLN/month; $S_{a}$ - the subscription fee rate, PLN/month; $m$ - the number of months in the billing period.

For energy prices, current average price levels in Poland were used as follows (1 Euro = 4.20 PLN):

- Electricity 0.71 PLN/kWh + VAT (23\%),

- Natural gas $0.32 \mathrm{PLN} / \mathrm{kWh}+$ VAT (23\%),

- District heating 0.28 PLN/kWh + VAT (23\%),

- Pellet 0.21 PLN/kWh + VAT (23\%).

\subsection{Methodology for the calculation of global cost}

Global costs of buildings and their components, including installations, are calculated as sum of the initial investment costs and the discounted annual operating costs during the calculation period. 
Global costs related to the initial year take into account the initial investment costs and the annual operating costs discounted during the calculation period, minus the residual value of each of the components taken into account. Analysis by means of the global costs method was performed using the following formulas (PN EN 15459:2008):

$$
C_{G}(\tau)=C_{i n, i n v}+\sum_{j=1}^{j_{x}}\left[\sum_{i=1}^{\tau}\left(\mathrm{C}_{\mathrm{a}, \mathrm{i}}(\mathrm{j}) \cdot R_{d}(i)\right)-V_{f, \tau}(j)\right],
$$

where: $C_{G}(\tau)$ - the global cost referred back to the starting year, PLN; $C_{i n \text {, inv }}$ - the initial investment costs, PLN; $j$ - the index of the component or system; $j_{x}$ - the number of components or systems; $\tau$ - the calculation period, $a ; C_{a, i}(j)$ - the annual costs for component or system $\mathrm{j}$ of the year i, PLN; $R_{d}(i)$ - the discount rate (for year $\mathrm{i}$ ); $V_{f, \tau}(j)$ - the final value of the component or system $j$ (corresponding to the calculation period $\tau$ ); in other words, the residual value of a measure or set of measures at the end of the calculation period (with respect to the initial year), PLN.

The time value of money taking into account the annual inflation rate and the market rate of interest can be described by formulas (7). The discount rate depends on the real interest rate $R_{R}$ and on the timing of the considered costs. To estimate the real interest rate 3 months WIBOR was taken into account. The Warsaw Interbank Offered Rate (WIBOR) for 10-year government bond provides a good estimator of the risk-free rate:

$$
R_{d}(p)=\left(\frac{1}{1+\frac{R_{R}}{100}}\right)^{p},
$$

where: $R_{d}(p)$ - the discount rate; $R_{R}$ - the real interest rate, $\% ; p$ - the number of years of operation of the building measured from the year zero.

$$
R_{R}=\frac{W I B O R-R_{i}}{1+\frac{R_{i}}{100}}
$$

where: $R_{R}$ - the real interest rate, \%; WIBOR - the Warsaw Interbank Offered Rate, \%; $R_{i}$ - the annual rate of inflation, \%.

The present value factor depends on the real interest rate $R_{R}$ and the number of years $\mathrm{n}$ considered for the annual costs:

$$
f_{p v}(n)=\frac{1-\left(1+\frac{R_{R}}{100}\right)^{-n}}{\frac{R_{R}}{100}},
$$

where: $f_{p v}(n)$ - the present value factor; $R_{R}$ - the real interest rate, $\% ; n$ - the number of years considered for the annual costs.

Energy costs represent the costs of energy consumption and fixed fees for its willingness to provide energy. If the calculation period $\tau$ includes the life time $\tau_{n}(j)$ of the considered component $(j)$, the last replacement cost is taken into account by assuming a linear reduction in its value: 


$$
V_{f, \tau}(j)=V_{o}(j) \cdot\left(1+\frac{R_{p}}{100}\right)^{n_{\tau}(j) \cdot \tau_{n}(j)} \cdot\left[\frac{n_{\tau}(j) \cdot \tau_{n}(j)-\tau}{\tau_{n}(j)}\right] \cdot R_{d}(\tau),
$$

where: $V_{o}$ - the investment cost, PLN; $n_{\tau}(j)$ - the total number of replacements of components $j$ throughout the calculation period; $R_{d}(t)$ - the discount rate at the end of the calculation period.

In the formula for the final value $V_{f, t}(j)$ individual components denote the cost of the last exchange with regard to the rate of increase in the prices of the product $\left(R_{p}\right)$ and the straight-line depreciation of the value of the component exchange, taking into account the remaining life time left after the last exchange.

\section{Reference building}

A case study was prepared for three types of residential buildings. The first two buildings are single-family houses where the heated unit area $A_{f}=164 \mathrm{~m}^{2}$. BSC_1 was assumed for free-standing buildings with the shape coefficient A/V $=0.67 \mathrm{~m}^{-1}, \mathrm{BSC} \_2$ was assumed for six-compound buildings $\left(\mathrm{A} / \mathrm{V}=0.45 \mathrm{~m}^{-1}\right)$, each compound with the same area and functional arrangement as BSC_1 buildings. The third building (BSC_3) is a typical multifamily building with a shape coefficient at the level of $\mathrm{A} / \mathrm{V}=0.37 \mathrm{~m}^{-1}$ and a heated area with the regulated temperature at the level $A_{f}=833 \mathrm{~m}^{2}$. The building represented a typical medium-sized multi-storey building in an urban context. $20^{\circ} \mathrm{C}$ was the assumed weighted arithmetic mean temperature in the buildings.

\subsection{Technical variants of the analysis}

Four different levels of insulation standards were defined - beginning with the heating energy demand SEB, which represents the minimum requirement according to the building regulations in the year 2013 (Dz.U. nr 201, poz. 1238. 2008), and ending at VLEB, which is representative of the insulation quality of a very low energy building standard.

Table 2 shows the variation of heat transfer coefficients of the building envelope, and the share of thermal bridging. The $\mathrm{SEB}^{\star}$ variant is a variant of SEB improved by about $15 \%$. For thermal variants from SEB to LEB the air tightness was assumed to be on the $\mathrm{n}_{50}=$ $3.0 \mathrm{~h}^{-1}$ level.

The variation of the insulation standard (variants SEB to VLEB) is the basic variation which is then repeated in combination with other technical measures as described below.

Upon the running analyses the following variants of the ventilation systems were foreseen:

- V1 natural (for natural ventilation, the infiltration was not taken into account),

- V2 hybrid (implemented through a higro-control air inlet and natural ventilation channels),

- V3 mechanical exhaust,

- V4 mechanical supply and exhaust air as a function of the load, 50\% of heat recovery,

- V5 mechanical supply and exhaust air as a function of the load, 70\% of heat recovery. 
Table 2. The heat transfer coefficient of building envelopes, the share of thermal bridges depending on the energy standard

\begin{tabular}{llcccc}
\hline \multicolumn{2}{c}{ Variants } & SEB & SEB $^{*}$ & LEB & VLEB \\
\hline \multirow{2}{*}{$\begin{array}{l}\text { U-value, } \\
\text { W/m }\end{array} / \mathrm{K}$} & wall & 0.30 & 0.25 & 0.20 & 0.15 \\
\cline { 2 - 6 } & ground floor & 0.45 & 0.35 & 0.30 & 0.20 \\
\cline { 2 - 6 } & roof & 0.25 & 0.20 & 0.16 & 0.12 \\
\cline { 2 - 6 } & door & 2.60 & 1.80 & 1.80 & 1.80 \\
\cline { 2 - 6 } & window & 1.80 & 1.30 & 1.30 & 0.90 \\
\hline \multicolumn{2}{c}{$\mathrm{g}^{(1)}$} & 0.70 & 0.60 & 0.60 & 0.55 \\
\hline thermal bridges in $H_{t r}, \%$ & 15 & 15 & 10 & 5 \\
\hline
\end{tabular}

Note: (1) coefficient of solar energy transmittance for solar radiation.

For all analysed variants 4 systems of energy supply were assumed, based on the usage of a gas condensing boiler (GCB variant), district heating (DH variant), a ground heat pump (GHP variant) and finally a pellet boiler (PB variant). Depending on the particular variant the efficiency of the regulation was differentiated from 93 to $99 \%$. The efficiency of the distribution was assumed at a constant level of 95\%. The producing efficiency depends on the chosen heat source and was assumed respectively: for GCB $-96 \%, \mathrm{DH}-91 \%$, GHP $-340 \%, \mathrm{~PB}-72 \%$. Taking into consideration the volatility of the building's envelope 7 variants for each of the four heat sources were analysed (Table 3).

Table 3. Description of the analysed variants

\begin{tabular}{lccccccc}
\hline Variants & TV_1 & TV_2 & TV_3 & TV_4 & TV_5 & TV_6 & TV_7 \\
\hline Building's & SEB & SEB $^{*}$ & LEB & LEB & VLEB & VLEB & VLEB \\
\hline Technical's & V1 & V2 & V3 & V4 & V4 & V5 & V5 \\
\hline
\end{tabular}

The TV_7 variant is the one where the value of the usable energy for the building was obtained at the level of $\mathrm{Q}_{\mathrm{H} \text { nd }}=15 \mathrm{kWh} / \mathrm{m}^{2} / \mathrm{a}$ and is equal to the values of the passive buildings.

\subsection{Investments costs}

The investment costs define the calculation of the price according to the agreed methods.

In Poland the price estimation of the given civil work (CK) is a sum of: the estimated value of the labour, the estimated value of the building materials, the estimated value of the building machines work, the costs of the building material purchase as well as indirect costs and VAT (value added tax).

Unit costs were assigned to individual categories, as follows:

- IC_1 - construction components affecting energy consumption - sun blinds,

- IC_2 - investment costs of installed equipment associated with the consumption of energy - chimneys, heat sources, central heating system, ventilation and hot water preparation, 
- IC_3 - construction investment costs affecting energy consumption - windows, thermal insulation,

- IC_4 - construction investment costs - building the envelope, plumbing the system, gas and electricity installations.

In the diagram (Fig. 1) a comparison of the investment building costs was presented for the analysed buildings, not related to the sources of heat applied to the building.

In the diagram (Fig. 2), there is a comparison of the investment costs of the in-

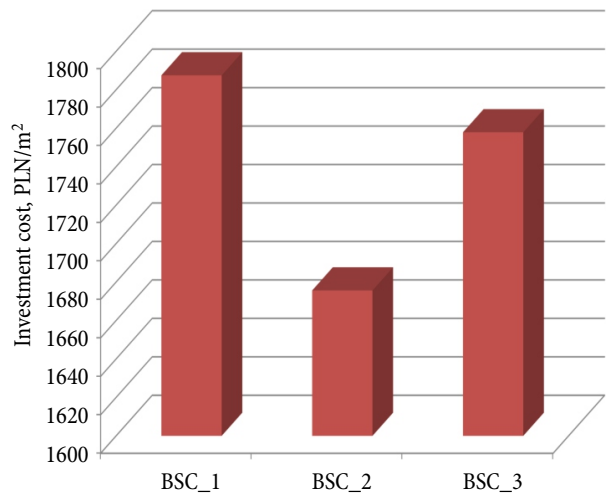

Fig. 1. The building unit costs for the analysed costs IC_4, PLN/m² stalled equipment related to energy usage.

The category consists of the costs related to construction of the internal ventilation ducts and the chimney, the installation of the heat source, the installation of the central heating system, the preparation of hot water and ventilation, the installation of windows and the application of the external blinds and the application of the thermal insulation to the building's partitions.
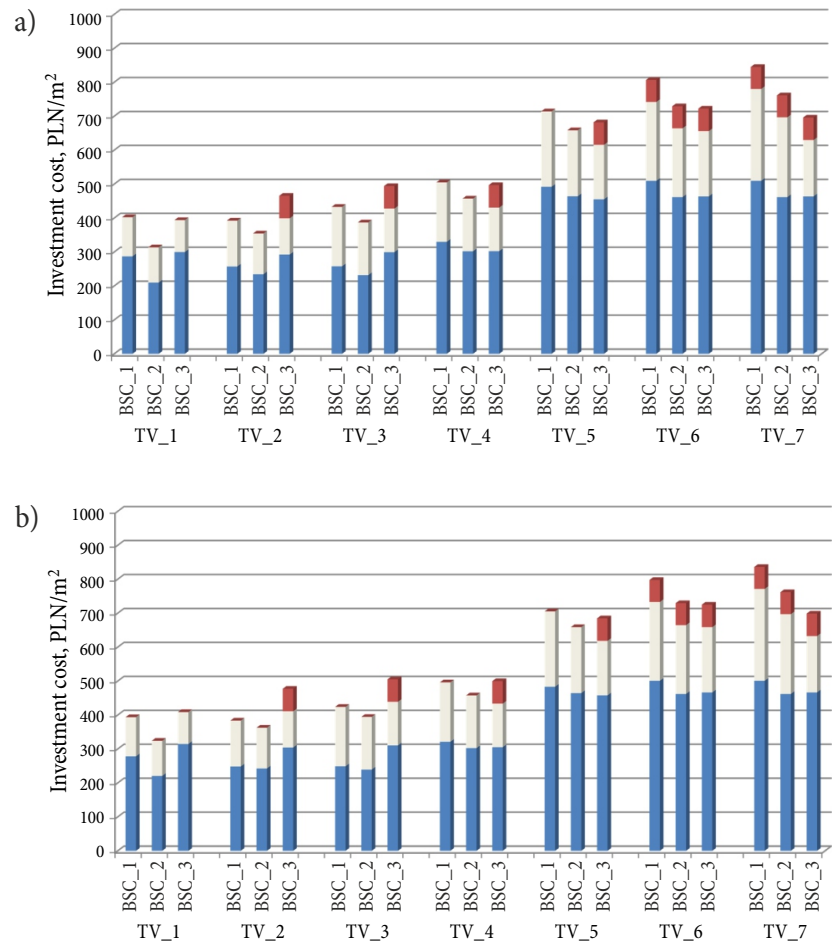

Fig. 2. To be continued 
c)

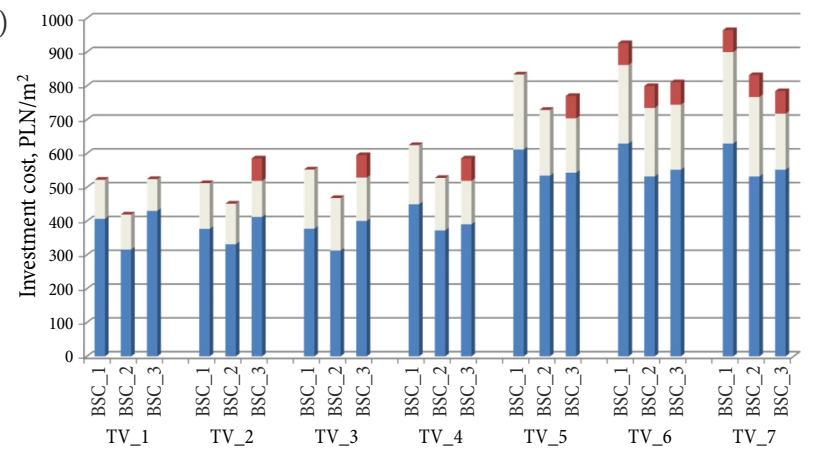

d)

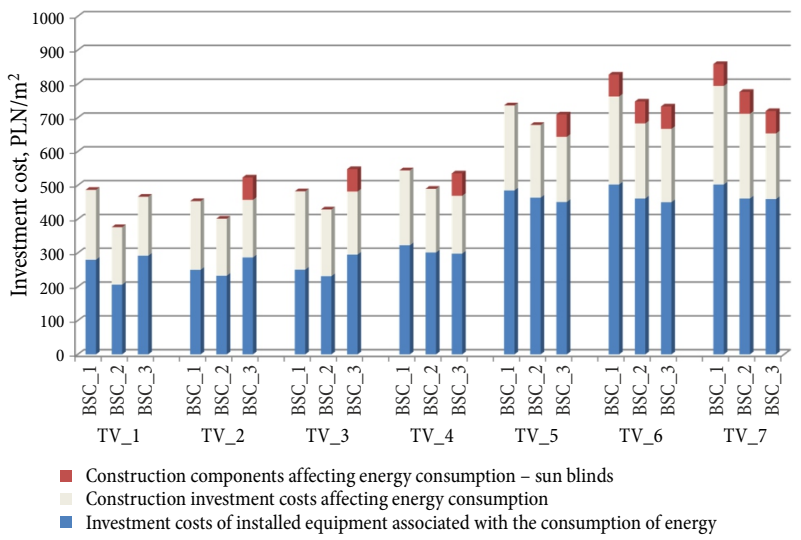

Fig. 2. The investment unit costs of the installed equipment related of the usage of the energy for the analysed buildings and the applied heat sources, PLN $/ \mathrm{m}^{2}$ : $\mathrm{a}-\mathrm{GCB} ; \mathrm{b}-\mathrm{DH} ; \mathrm{c}-\mathrm{GHP} ; \mathrm{d}-\mathrm{PB}$

\section{Choice of solution according to the optimal global cost}

The general assumptions were taken into consideration during an evaluation of the effectiveness of the applied technical solutions according to standard (PN EN 15459: 2008). The analysis includes fixed macro-economic parameters: inflation $-0.5 \%$, increase in energy prices $-0.5 \%$, market interest rate (cost of money - WIBOR) -3.0 .

\subsection{Primary energy}

The value of primary energy used for hot water preparation in case of the buildings is constant and independent of the analysed technical variant, and this is also the case, depending on the heat source, for single-family buildings $E P_{W}{ }^{G C B}=19.9 \mathrm{kWh} / \mathrm{m}^{2} / \mathrm{a}-$ for a gas condensing boiler up to the value $E P_{W}{ }^{P B}=4.5 \mathrm{kWh} / \mathrm{m}^{2} / \mathrm{a}$ for a pellet boiler, and for a multi-family building, respectively $E P_{W}{ }^{G C B}=34.0 \mathrm{kWh} / \mathrm{m}^{2} / \mathrm{a}$ and $E P_{W}{ }^{P B}=7.7 \mathrm{kWh} / \mathrm{m}^{2} / \mathrm{a}$.

The improvement in the building's envelope and control over the in-taking of air to the building results in a decreasing primary energy index. For the gas condensing boiler, 
the building BSC_1 decreases by $71 \%$, the building BSC_2 by $69 \%$, the building BSC_3 by $53 \%$. Also, the share of energy for heating and ventilation decreases, but at the same time the share of energy for preparation of hot water and auxiliary energy increases. The biggest share of auxiliary energy in the primary energy index value is for the pellet boiler and for the variant TV_7, which on average, for the analysed buildings, can value up to 59\%. The low values of primary energy for the pellet boiler result from the coefficient of the investment for Polish conditions, assumed in the analysis at the level of $w_{H}=0.2$.

\subsection{Analysis of the variability of global cost}

Detailed analysis of global costs dependant on the character of technical parameters changes was presented for the analysed buildings and the heat sources in the graphs below (Fig. 3).

When comparing, in relation to the initial variant TV_1, the variability of the increase in global costs with the improvements in the energy characteristics of the building, we observe that the global costs of the single-family buildings decrease down to the TV_3 variant, and then increase, while in case of the multi-family building they increase for all areas of the characteristics, except for the TV_4 variant. The usage of better ventilation units results in an increase in global costs for both single-family and multi-family buildings.

a)

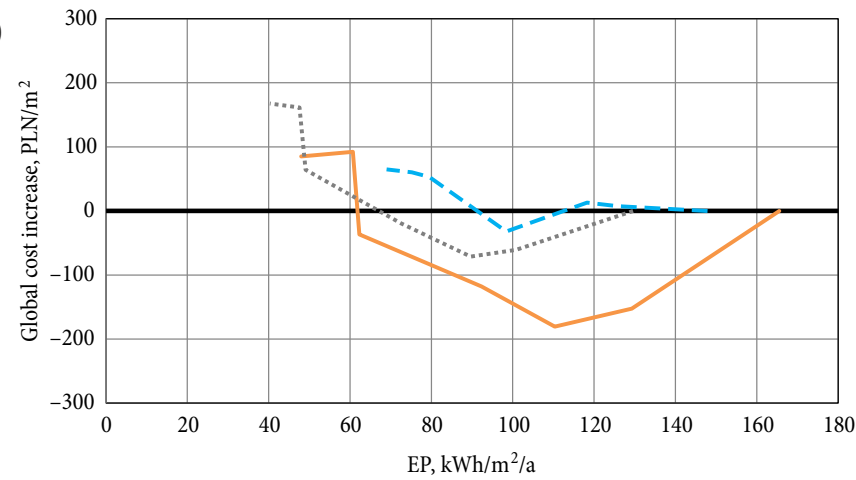

b)

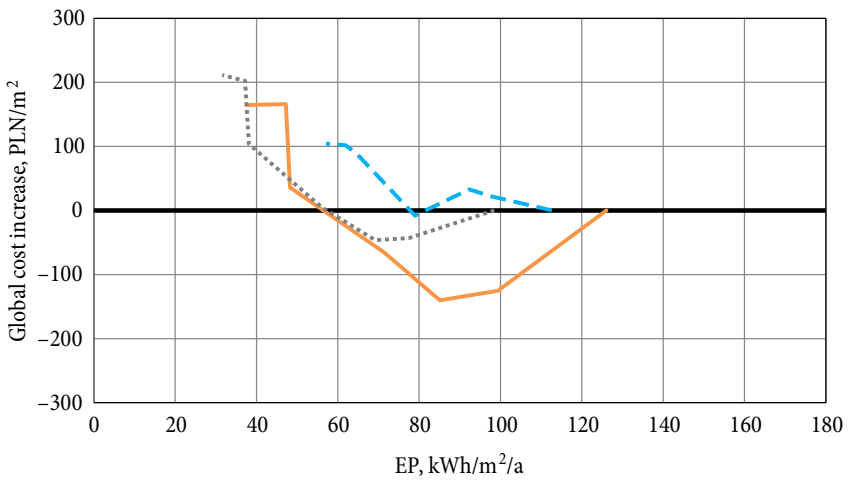

Fig. 3. To be continued 
c)

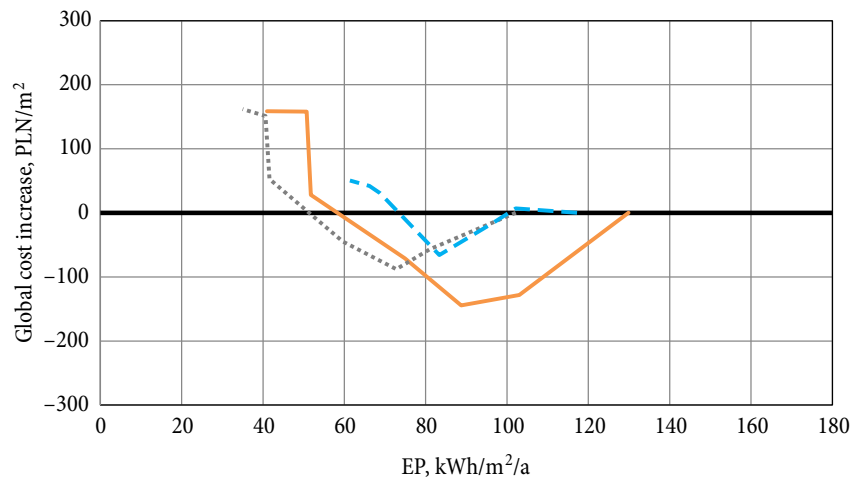

d)

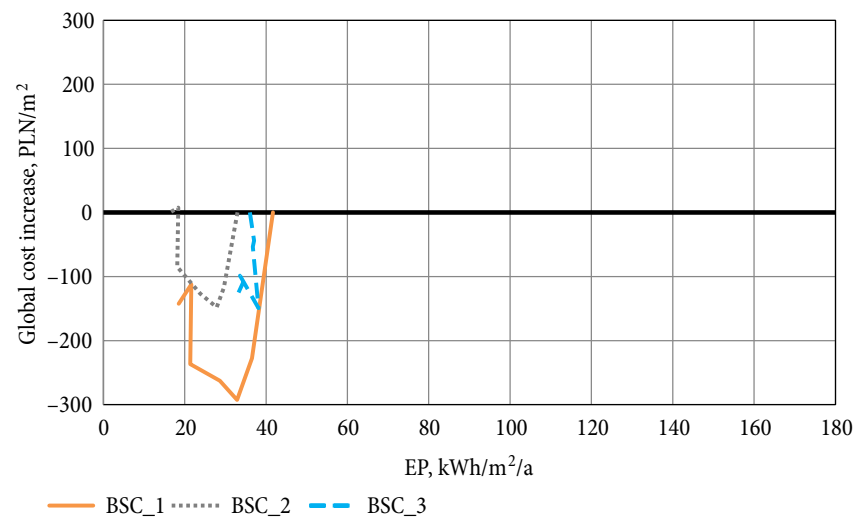

Fig. 3. The absolute change in global costs in relation to the TV_1 technical variant for the analysed buildings and the different heat sources, $\mathrm{kWh} / \mathrm{m}^{2} / \mathrm{a}$ : a - GCB; $\mathrm{b}-\mathrm{DH} ; \mathrm{c}-\mathrm{GHP} ; \mathrm{d}-\mathrm{PB}$

\subsection{Optimum primary energy index}

Using the global costs method, based on the 7 items of variability for the primary energy index (TV_1 up to TV_7) for each building and the analysed heat source, the optimal level for the primary energy index $\left(\mathrm{EP}_{\mathrm{opt}}\right)$ was defined (Fig. 4).

Achieving the minimum global costs is related to decreasing the EP index in relation to the heat requirements valid in Poland in 2013, on average, by $27.3 \%$.

Depending on the heat source applied in the building, the optimal $E P_{o p t}$ in terms of global costs varies. It has the lowest value for pellet boiler, and the biggest - for the gas condensing boiler - the most popular solution in newly constructed buildings in Poland. The difference, related to the global costs between the sources in the building, results mainly from the costs of the heat source and the energy. In the case of the pellet boiler, the additional costs of the service were taken into account. $E P_{o p t}$ values are getting lower along with a lowering of the building shape index.

Table 4 shows a summary of the optimal level for the primary energy index, indicated by the global costs method for the analysed buildings and heat sources, comparing the requirements which were successively introduced in Poland. 
a)

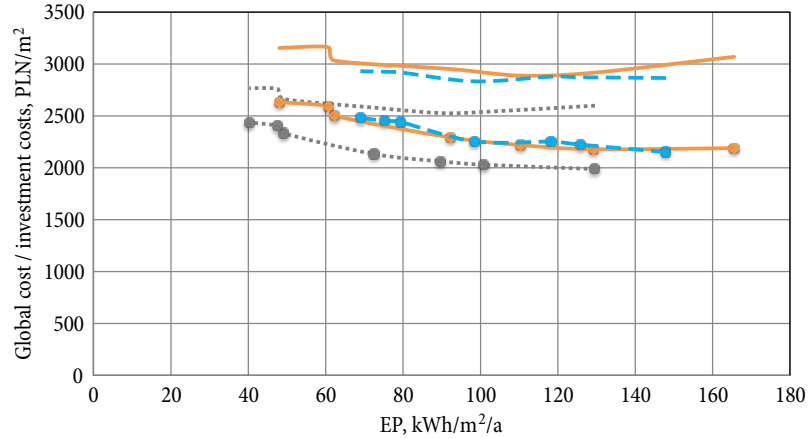

b)

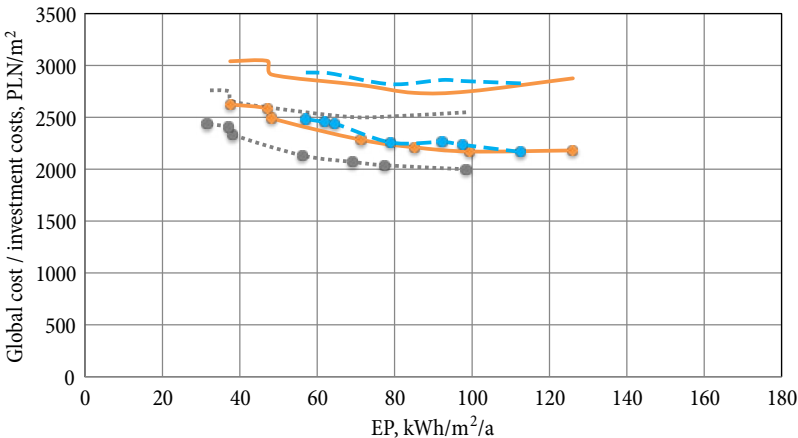

c)

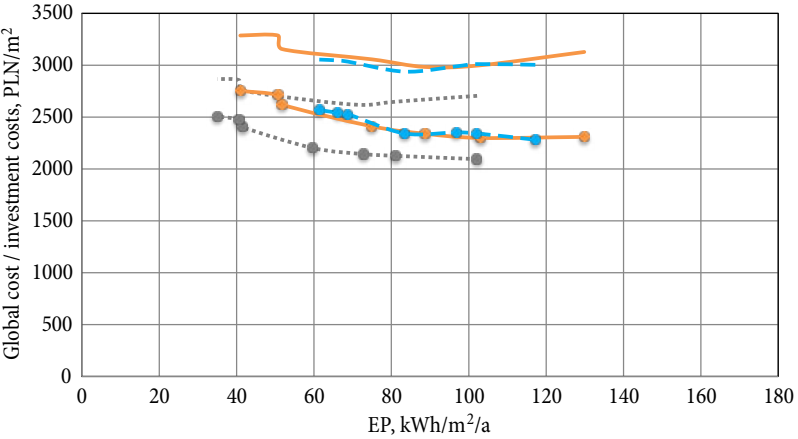

d)

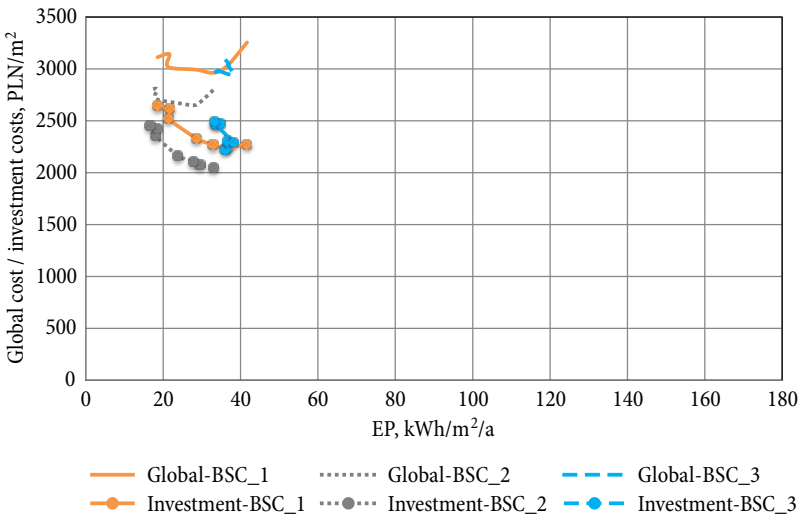

Fig. 4. The variability of global costs for the analysed buildings and the different heat sources in $\mathrm{kWh} / \mathrm{m}^{2} / \mathrm{a}$ : a - GCB; b - DH; c - GHP; $\mathrm{d}-\mathrm{PB}$ 
Table 4. Optimal level for the primary energy index for the analysed buildings and heat sources including the requirements regarding the building's thermal insulation, $\mathrm{kWh} / \mathrm{m}^{2} / \mathrm{a}$

\begin{tabular}{ccccc}
\hline \multirow{2}{*}{ Building } & \multicolumn{5}{c}{$E P_{\text {opt }}, \mathrm{kWh} / \mathrm{m}^{2} / \mathrm{a}$} \\
\cline { 2 - 5 } & GCB & DH & GHP & PB \\
\hline BSC_1 & 114.0 & 89.6 & 93.8 & 32.6 \\
\hline BSC_2 & 92.2 & 72.0 & 73.3 & 27.8 \\
\hline BSC_3 & 100.0 & 83.0 & 84.5 & - \\
\hline
\end{tabular}

According to the presently valid rules the permissible value of primary energy for the purpose of heating, ventilation and hot water preparation for the single-family building reaches the level of $120 \mathrm{kWh} / \mathrm{m}^{2} / \mathrm{a}$, while for the multi-family building it is $105 \mathrm{kWh} / \mathrm{m}^{2} / \mathrm{a}$ (Dz.U. poz.926. 2013). The Polish government introduced a programme for achieving the heat requirements of the low-energy standard, successively decreasing the permissible primary energy indexes by $20 \%$ and then $40 \%$ in the following years: 2014,2017 and finally 2021. From this analysis, the results show that achieving the requirements in the future will be possible only if changes are introduced not only to the thermal envelope of the building but also and first of all to the system of air flow control and the choice of heat source based on renewable energy sources.

\section{Polish support instruments for the low-energy construction industry}

\subsection{Proposed instruments}

In connection with the European Union requirements for improving the thermal protection of buildings, Poland introduced subsidies for the construction of low-energy buildings.

In 2013, the National Fund for Environmental Protection and Water Management introduced a priority program constituting a national support instrument for people constructing residential buildings with low energy consumption, and designed to help investors, designers and contractors to implement the main objective of the Directive. Support for individuals building energy efficient houses is realized in the form of subsidies or bank loans. The primary endpoint of the residential building is the NF ratio, the value of which stems from the quotient $Q_{H, n d}$ (energy needs for heating and ventilation, $\mathrm{kWh} / \mathrm{m}^{2} / \mathrm{a}$ ) referred to the conditioned floor area with a controlled temperature. In addition, some other requirements need to be met, including the efficiency of the heating system and hot water preparation. Depending on the obtained standard, the Polish government provides a subsidy at the amount of (NFOŚ 2015):

- for a single-family detached building, standard NF40 - 30000 PLN/building,

- for a single-family detached building, standard NF15 - 50000 PLN/building,

- for a multi-family building, standard NF40 - 11000 PLN/apartment,

- for a multi-family building, standard NF15 - 16000 PLN/apartment. 


\subsection{Investment costs for a building to achieve a low energy standard}

To achieve a standard of energy need at the level of NF40 or NF15 one should increase investment costs at the execution stage, mainly on the side of the investment costs of installed equipment associated with power consumption and construction investment costs that affect energy consumption, which include costs associated with the installation of windows with better thermal characteristics and extra thick insulation that meets the criteria for thermal protection of the building.

Based on the example of the analyses of buildings with a gas-fired boiler, Figure 5 shows the variability of investment costs, depending on the thermal characteristics of the building with the corresponding energy need ratios at the level of NF15 and NF40. For residential buildings: a detached single-family - BSC_1 and terraced - BSC_2, the initial assumptions adopted guarantee meeting the NF15 standard; for a multi-family dwelling - BSC_3, due to the high share of needs for hot water preparation in primary energy, the NF15 standard for the building is difficult to achieve without additional improvements especially in the area of hot water preparation.

a)

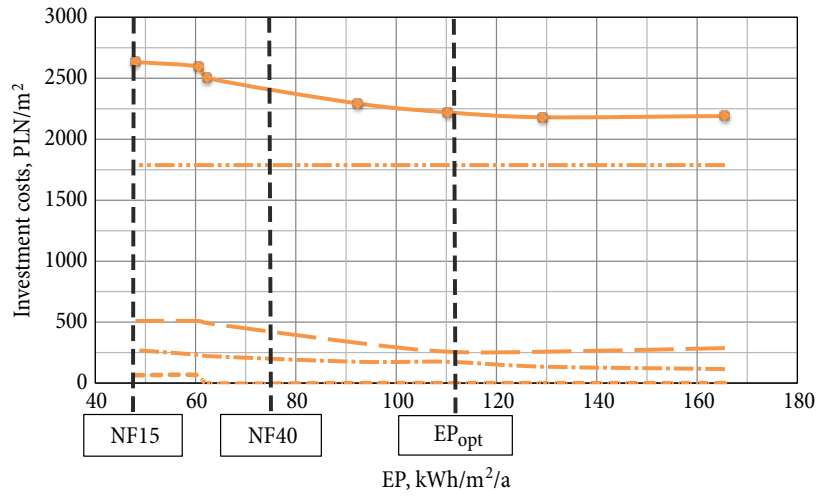

b)

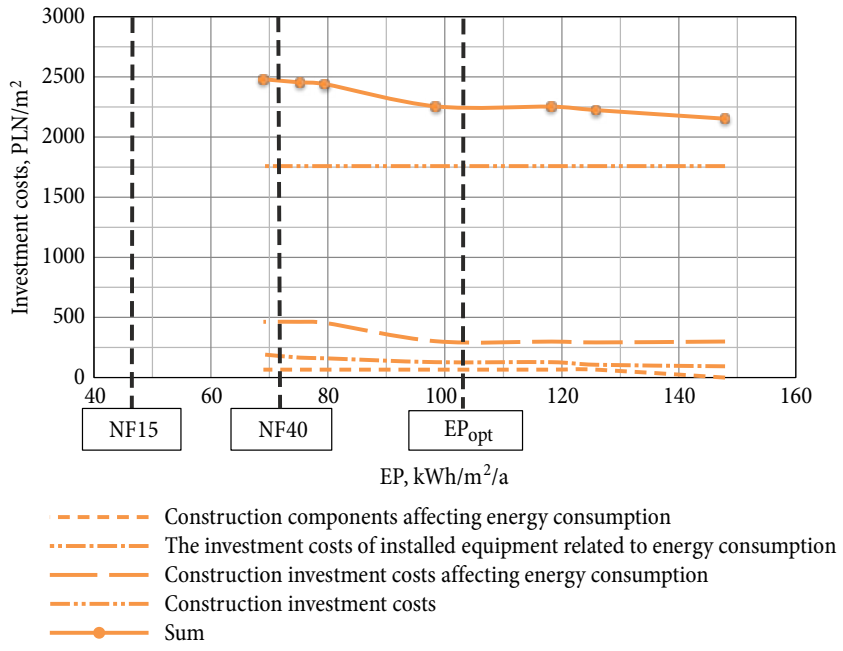

Fig. 5. Characteristics of investment costs for the reference buildings and gas condensing boilers: BSC_1; b - BSC_3 
Depending on the building analyzed, and the heat source used, the investment costs are at the level presented in Table 5.

For a detached single-family building and a terraced building, in order to achieve the NF40 standard, an average rise of $6.5 \%$ in investment costs should be expected when compared to the costs of the construction of buildings according to the standard for thermal requirements in force in 2013 in Poland, for a multi-family building the costs increase is lower and amounts to $3.7 \%$. In order to achieve the NF15 standard, increases of $19.2 \%$ and $12.9 \%$ respectively are incurred.

Table 5. Rise in investment costs $\left[\mathrm{PLN} / \mathrm{m}^{2} / \mathrm{a}\right.$ ] necessary to implement NF40 and NF15 standards for the analyzed buildings and heat sources with reference to the requirements in force in 2013 in Poland, 1 Euro $=4.20$ PLN

\begin{tabular}{cccccccccc}
\hline & & \multicolumn{2}{c}{ GCB } & \multicolumn{2}{c}{ DH } & \multicolumn{2}{c}{ GHP } & \multicolumn{2}{c}{ PB } \\
\hline & & PLN & $\%$ & PLN & $\%$ & PLN & $\%$ & PLN & $\%$ \\
\hline BSC_1 & NF40 & 198 & 9.0 & 199 & 9.1 & 202 & 8.7 & 146 & 6.4 \\
\hline & NF15 & 442 & 20.2 & 443 & 20.3 & 442 & 19.1 & 372 & 16.4 \\
\hline BSC_2 & NF40 & 116 & 5.8 & 100 & 5.0 & 82 & 3.9 & 88 & 4.3 \\
\hline & NF15 & 416 & 20.9 & 405 & 20.3 & 380 & 18.1 & 372 & 18.1 \\
\hline BSC_3 & NF40 & 102 & 4.7 & 85 & 3.9 & 54 & 2.4 & - & - \\
\hline & NF15 & 302 & 14.0 & 290 & 13.4 & 260 & 11.4 & - & - \\
\hline
\end{tabular}

The observed increase in the investment prices and global costs related to the construction of the low-energy building is a common phenomenon and it does not depend on the country. The presented analyses give us the opportunity to establish the proportions of price changes so they can be used during the planning process of technical solutions for low-energy and passive buildings in each country where the European Directives - regarding energy saving - were or are implemented. The results will also be applicable in the Baltic countries.

\subsection{Evaluation of existing credit support instruments by means of the global costs method}

In the case of a detached single-family building (BSC_1) and a terraced house (BSC_2) a subsidy of 30 thousand PLN is at the borderline of the price increases associated with achievement of the NF40 standard. In order to achieve the standard of NF15, an increase in costs by about $45 \%$ above a granted subsidy of 50 thousand PLN should be expected. Developers, whose apartment price can include a loan subsidy covering the price increase resulting from the improvements to the thermal characteristics of the building regardless of the expected standard, are in a comfortable position. Taking into account the real estate market demand for small apartments, their situation is even better.

In addition to the construction costs, a subsidy also includes funds for the banking services of banks cooperating with the Fund and the verifier's fee. The beneficiary is required to pay income tax related to the granted financial support. 
In a case where the assumed NF15 standard is not achieved, the subsidy may be reduced to the level provided for by the standard NF40. When the assumed NF40 standard is not achieved, the subsidy will not be granted.

\section{Conclusions}

Each member country of the European Union is obliged, by means of a Directive, to save energy and popularize the construction of low-energy buildings.

This paper uses the provisions of the transformed EPBD directive to evaluate the possibilities of achieving low-energy standards for residential buildings in Polish conditions. For evaluation, the global costs method was chosen, as this method allows for complex estimation of the building along with its networks, taking into consideration the costs related to exploitation. The method mentioned above gives the opportunity to forecast the proportions of price changes during the planning of sustainable buildings, though one needs to be careful when shifting the absolute values of the costs to the situation in a different country.

The Polish state, tending toward a decrease in primary energy, introduced the priority programme as an instrument to support those who build residential buildings with low levels of energy consumption. The participants in this programme are 6 banks which provide the preferential loans for the goal described above.

Since the beginning of 2013, the number of provided loans has been small, which means that the proposed tool is unattractive, as it is connected to requirements which are the difficult to fulfil and inadequate grants which are not sufficient to fully cover the additional costs related to the NF15 standard's achievement. The change in the economic parameters, especially in the case of the unstable Polish market economy, may mean that investments which were assumed to be unprofitable become profitable due to the change in economic conditions.

The presented algorithm of cost estimation for low-energy buildings and the evaluation of subsidies can be used in all countries executing the provisions of the EU Directive. It can be applied in the preparation of practical recommendations for decision-making bodies when taking certain decisions regarding the form and volume of the supporting instruments. But the necessity of undertaking sensitivity analysis must be taken into account, as sensitivity analysis is important to the process of establishing energy performance for buildings because economic changes will lead to changes in macroeconomic parameters and requirements over time.

In conclusion, the global cost model as presented in this paper was shown to be an adaptable tool for assessing buildings. The model considered all life cycle stages to assist policy makers and designers in understanding the true national, regional and global impact of buildings on the environment. 


\section{References}

Aelenei, L.; Paduos, S.; Petran, H.; Tarrés, J.; Ferreira, A.; Corrado, V.; Camelo, S.; Polychroni, E.; Sfakianaki, K.; Gonçalves, H.; Salom, J.; Riva, G.; Murano, G. 2015. Implementing cost-optimal methodology in existing public buildings, Energy Procedia 78: 2022-2027. http://dx.doi.org/10.1016/j.egypro.2015.11.197

Aviža, D.; Turskis, Z. 2014. An empirical analysis of correlation between the thickness of a thermal insulation layer of the floor and the payback period, Journal of Civil Engineering and Management 20(5): 760-766. http://dx.doi.org/10.3846/13923730.2014.937356

Aviža, D.; Turskis, Z.; Kaklauskas, A. 2015. A Multiple criteria decision support system for analyzing the correlation between the thickness of a thermo-insulation layer and its payback period of the external wall, Journal of Civil Engineering and Management 21(6): 827-835. http://dx.doi.org/10.3846/13923730.2015.1046910

Basinska, M.; Koczyk, H.; Kosmowski, A. 2015a. Assessment of thermo modernization using the global cost method, Energy Procedia 78: 2040-2045. http://dx.doi.org/10.1016/j.egypro.2015.11.204

Basinska, M.; Koczyk, H.; Szczechowiak, E. 2015b. Sensitivity analysis in determining the optimum energy for residential buildings in Polish conditions, Energy and Buildings 107: 307-318. http://dx.doi.org/10.1016/j.enbuild.2015.08.029

Chidiac, S. E.; Catania, E. J. C.; Morofsky, E.; Foo, S. 2011. A screening methodology for implementing cost effective energy retrofit measures in Canadian office buildings, Energy and Buildings 43(2-3): 614-620. http://dx.doi.org/10.1016/j.enbuild.2010.11.002

Directive 2010/31/EU of the European Parliament and of the Council of 19 May 2010 on the energy performance of buildings, Official Journal of the European Union.

Dz.U. nr 201, poz.1238. 2008. Rozporządzenie Ministra Infrastruktury zmieniajace rozporzadzenie w sprawie warunków technicznych, jakim powinny odpowiadać budynki i ich usytuowanie. Polish law (in Polish).

Dz.U. nr 201, poz.1240. 2008. Rozporzadzenie Ministra Infrastruktury w sprawie metodologii obliczania charakterystyki energetycznej budynku i lokalu mieszkalnego lub części budynku stanowiacej samodzielna całość techniczno-użytkowa oraz sposobu sporządzania i wzorów świadectw ich charakterystyki energetycznej. Polish law (in Polish).

Dz.U. poz.926. 2013. Rozporzadzenie Ministra Transportu, Budownictwa i Gospodarki Morskiej zmieniające rozporządzenie w sprawie warunków technicznych, jakim powinny odpowiadać budynki i ich usytuowanie. Polish law (in Polish).

Kurnitski, J.; Kuusk, K.; Tark, T.; Uutar, A.; Kalamees, T.; Pikas, E. 2014. Energy and investment intensity of integrated renovation and 2030cost optimal savings, Energy and Buildings 75: 51-59. http://dx.doi.org/10.1016/j.enbuild.2014.01.044

Kurnitski, J.; Saari, A.; Kalamees, T.; Vuolle, M.; Niemela, J.; Tark, T. 2011. Cost optimal and nearly zero (nZEB) energy performance calculations for residential buildings with REHVA definition for nZEB national implementation, Energy and Buildings 43: 3279-3288.

http://dx.doi.org/10.1016/j.enbuild.2011.08.033

Kurnitski, J.; Saari, A.; Kalamees, T.; Vuolle, M.; Niemelä, J.; Tark, T. 2013. Cost optimal and nearly zero energy performance requirements for buildings in Estonia, Estonian Journal of Engineering 19(3): 183-202. http://dx.doi.org/10.3176/eng.2013.3.02

MIiD. 2015. Ministry of Infrastructure and Development, Poland [online], [cited 25 July 2015]. Available from Internet: www.mir.gov.pl

NFOS. 2015. The National Fund for Environmental Protection and Water Management, Poland [online], [cited 24 August 2015]. Available from Internet: www.nfosigw.gov.pl. 
Ouyang, J.; Wang, Ch.; Li, H.; Hokao, K. 2011. A methodology for energy-efficient renovation of existing residential buildings in China and case study, Energy and Buildings 43: 2203-2210. http://dx.doi.org/10.1016/j.enbuild.2011.05.005

Pikas, E.; Kurnitski, J.; Liias, R.; Thalfeldt, M. 2015. Quantification of economic benefits of renovation of apartment buildings as a basis for cost optimal 2030 energy efficiency strategies, Energy and Buildings 86: 151-160. http://dx.doi.org/10.1016/j.enbuild.2014.10.004

PN EN 15251:2012 Criteria for the indoor environment, including thermal conditions, indoor air quality, lighting and noise. Polish Standards Institution, Warsaw.

PN EN 15459:2008 Energy performance of buildings - economic evaluation procedure for energy systems in buildings. Polish Standards Institution, Warsaw.

Ruzgys, A.; Volvačiovas, R.; Ignatavičius, Č.; Turskis, Z. 2014. Integrated evaluation of external wall insulation in residential buildings using SWARA-TODIM MCDM method, Journal of Civil Engineering and Management 20(1): 103-110. http://dx.doi.org/10.3846/13923730.2013.843585

Tupenaite, L.; Zavadskas, E. K.; Kaklauskas, A.; Turskis, Z.; Seniut, S. 2010. Multiple criteria assessment of alternatives for built and human environment renovation, Journal of Civil Engineering and Management 16(2): 257-266. http://dx.doi.org/10.3846/jcem.2010.30

Małgorzata BASIŃSKA. PhD in Environmental Engineering at the Poznan University of Technology, Poland. Senior Lecturer at the Department of Heating, Air Conditioning and Air Protection Institute of Environmental Engineering. M Sc. (Eng.) diploma in 1991, PhD in 2000 at Poznan UT. Research interests: heat transfer in buildings, outdoor climate, internal environment, microorganism contamination.

Halina KOCZYK. Prof., PhD in Environmental Engineering at the Poznan University of Technology, Poland. Professor in the Department of Heating, Air Conditioning and Air Protection Institute of Environmental Engineering. M Sc. (Eng.) diploma in 1970, PhD in 1978, habilitation in 1990 at Poznan UT. Research interests: heat transfer in buildings, energy savings, internal environment, energy storage. 